\title{
Reply: On the clinical relevance of circulating endothelial cells and platelets in prostate
} cancer

C K E Wong ${ }^{1}$, B Namdarian ${ }^{2}$, J Chua ${ }^{1}$, X Chin ${ }^{1}$, R Speirs $^{1}$, T Nguyen $^{2}$, M Fankhauser $^{2}, \mathrm{~J} \mathrm{Pedersen}^{3}$, A J Costello ${ }^{1,2}$, N M Corcoran ${ }^{1,2}$ and C M Hovens ${ }^{\star, 1,2}$

${ }^{1}$ Australian Prostate Cancer Research Centre at Epworth Hospital, Richmond, Victoria, Australia; ${ }^{2}$ Department of Surgery, University of Melbourne, Royal Melbourne Hospital, Parkville, Victoria, Australia and ${ }^{3}$ TissuPath Pty Ltd, Glen Waverly, Victoria, Australia

Sir,

Bertolini et al (2013) make a valid observation that in using multiparametric flow cytometry techniques, the enumeration of a potentially wide variety of cell types and derived microparticles is possible, and that by including nucleic acid specific dyes, nuclear (i.e., CECs) vs anuclear (i.e., mature platelets) cell types can also be potentially identified.

For our study (Wong et al, 2012) we did initially use a DNA dye (7AAD) to discriminate dead cells from live cells in EDTA blood samples that were analysed for CECs and CEPs. Most of the cells within the CD31 + CD45 - population were negative for 7AAD staining, indicating that these cell were viable. However, we also noted that the number of CD31 + CD45 - cells did not differ significantly when analysed with or without the addition of 7AAD and hence did not include this dye in our further analyses.

In retrospect, it is also interesting to note that if cells without DNA content (either live/dead cells) were excluded in our initial analysis, we would not have observed the data pertaining to large immature platelets in this study, as we would have simply excluded them from the analysis along with other non-relevant microparticles and DNA-free-containing cells. As shown in our study, these large immature platelets are potential candidate biomarkers of disease status in recurrent/micrometastatic prostate cancer following surgery.

While our data does not support a role for enumeration of CECs in this setting, this does not preclude their potential utility as biomarkers in the more advanced disease setting as pointed out by
Bertolini et al (2013) in their references to the work of Ning et al (2010) and Strijbos et al (2010).

Clearly, screening methodologies, which can permit enumeration of multiple markers at the same time, offer the best means to discover and then validate the relevance of biomarkers in clinically relevant settings.

\section{REFERENCES}

Bertolini F, Shaked Y, Mancuso P (2013) On the clinical relevance of circulating endothelial cells and platelets in prostate cancer. Br J Cancer 108(6): 1387.

Ning YM, Gulley JL, Arlen PM, Woo S, Steinberg SM, Wright JJ, Parnes HL, Trepel JB, Lee MJ, Kim YS, Sun H, Madan RA, Latham L, Jones E, Chen CC, Figg WD, Dahut WL (2010) Phase II trial of bevacizumab, thalidomide, docetaxel, and prednisone in patients with metastatic castration-resistant prostate cancer. J Clin Oncol 28(12): 2070-2076.

Strijbos MH, Gratama JW, Schmitz PI, Rao C, Onstenk W, Doyle GV, Miller MC, de Wit R, Terstappen LW, Sleijfer S (2010) Circulating endothelial cells, circulating tumour cells, tissue factor, endothelin-1 and overall survival in prostate cancer patients treated with docetaxel. Eur J Cancer 46(11): 2027-2035.

Wong CKE, Namdarian B, Chua J, Chin X, Speirs R, Nguyen T, Fankhauser M, Pedersen J, Costello AJ, Corcoran NM, Hovens CM (2012) Levels of a subpopulation of platelets, but not circulating endothelial cells, predict early treatment failure in prostate cancer patients after prostatectomy. Br J Cancer 107(9): 1564-1573. 